\title{
超電導マグネット含浸材（エポキシ樹脂） に対する照射効果の一考察
}

\author{
西嶋茂宏 ・岡田東一 \\ 大阪大字工学部原子力工学教窒 大阪府吹田市字山田上 \\ (1976年12月 6 日受理)
}

\begin{abstract}
A Statistical Treatment of LNT Irradiation Effects on Mechanical Properties of Epoxy Resin for Potting in the Superconducting Magnets

Shigehiro Nishijima and Touichi Okada
\end{abstract}

\begin{abstract}
Department of Nuclear Engineering, Faculty of Engineering, Osaka Univ. Yamadakami, Suita, Osaka
\end{abstract}

(Received Dec. 6, 1976)

\section{Synopsis :}

An organic potting material, Epoxy Resin, was exposed to $r$-rays at the liquid nitrogen temperature $77 \mathrm{~K}$ and its mechanical properties such as elastic modulus, breaking stress, and breaking strain, were measured at the same temperature.

The gamma-irradiation exceeding $10^{7} \mathrm{R}$ led to small reduction of elastic modulus, which was concluded due to the cleavage of principal chain of polymer. The frequency distribution of the measured values concerning structure-sensitive properties such as breaking stress and/ or breaking strain was found not to fit the Gaussian curve after irradiation. This distribution had a tail component in the lower region, which suggested an introduction of "local" weak spots in potting material of the superconducting magnets during operation under irradiation.

\section{1. 緒言}

超電導マグネットには，使用条件によっては電磁力 のために線材が動き(Wire Movement), そのため電 流忿化現象 (Degradation) が起こる。また励磁する 際, 励磁を数回〜10数回繰り返さなければ設計電流值 が達成されないという，いわゆるトレーニング現象が 起こる。この原因の一つも Wire Movement である と考えられている112)。

現在, Wire Mevement を抑えるために, 超電導マ グネットを有機材で含浸したり，ポッティングしたり する方法がとられている。しかし完全にWire Movement を抑えることができるといらわけでなく，含浸 材に機械的欠宿が生じると，その箇所に Wire Movement が再び生じ, Degradation や Training が起こ
る2)。それゆえ，含浸材の機械的欠陥を支配寸る因子 が，Wire Movement を支配すると仮定し，機械的欠 陷の支配因子として次のようなものを考えた。

(i) 弾性係数

(ii) 破断点応力，破断点ひずみ

(iii) 熱膨張係数（膨張係数の差による熱応力）

(iv) 線材との接着性

さて超電導マグネットの応用は広範囲に及んでいる が，特に核物理への応用，さらには核融合への応用な どでは，かなりの放射線を受けるので，マグネットの 安全性, 安定性に対する放射線の影響考考慮する必要 がある。たとえば超電導マグネットが, 実用規模の核 融合炉で使用された場合, 速中性子で $10^{18} \mathrm{n} / \mathrm{cm}^{2}, \gamma$ 線で $10^{17 \gamma}$ (photons) $/ \mathrm{cm}^{2}\left(10^{8} \mathrm{R}\right)$ の放射線による照射 が考えられ, Streaming や安全係数を考慮すると, 
少くとも速中性子で $10^{20} \mathrm{n} / \mathrm{cm}^{2}$, 線で $10^{19 \gamma} / \mathrm{cm}^{2}\left(10^{10} \mathrm{R}\right)$ の照射 を受ける場合を考えておか叔ばな らないだちら ${ }^{334)}$

マグネットの放射線照射効果に ついては, マグネットの各構成要 素に分けた研究が，いくつかなさ れている(5)。しかし放射線に対し て比較的敏感であると思われる有

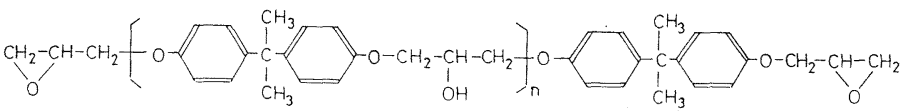

Fig. 1 The structure formula of Bisphenol-A type Epoxy Resin. The value of " $\mathrm{n}$ " is estimated from the second transition point to range from 8 to 11 in the sample used here. The quaternary carbon atoms and oxygen linked bonds in the principal chain are said comparatively unstable both against heat and radiation.

機含浸材に対する照射効果についての研究は非常に少 ない。

特に液体へリウム温度の照射実験は，多くの試料を 検查与る必要がある機械的性質の研究に招いては, 非 常な困難を伴う。ところが，有機絶縁材料の上らな物 質の種々の性質の温度依存性については, 常温と液体 窒素温度の変化の結果から, 液体へリウム温度近くの 挙動について, ある程度の予測を立て得る場合があ る*。

そこでわれわれは，実用超電導マグネット含浸材に ついて, 液体窒素温度で $\gamma$ 線を照射し, 压縮試験を行 ない，この含浸材の低温での機械的性質の変化 ( ( i ) (ii)）について，統計的に検討したので，その結果老 報告する。

\section{2. 試 料}

試料注実用エポキシ系含浸材 (6861 2) である。こ の樹脂の主成分はビスフェノールA系の樹脂で, Fig. 1 で示される一般構造式を持ち, エポキシ系樹脂の代 表的なものである。 $\mathrm{n}$ 注反応条件によって変化させる ことができるが，本実験の $\mathrm{n}$ は 8 11 程度で，分子量 にして平均 3,000 4,000 程度である。(軟化点から の推定）この樹脂を, $150^{\circ} \mathrm{C}$ で12時閒で硬化させ, 直 径 $1 \mathrm{~mm}$ 高さ $1.5 \mathrm{~mm}$ の円柱状の試料を製作した。な おこの樹脂は，全くの不定形のもので，機械的性質に 対する異方性はないと考えてよい。またこの樹脂で は, 第 4 級の炭素及び C-0 結合が, 放射線に対して 不安定であるといわれている8)。

*たとえば, 絶緣材料の熱収縮量の大部分は液体窒 素温度にまで泠却される際に生じてしまい, さらに 液体へリウム温度志で冷却しても, その収縮量はわ ずかである。したがって, 液体窒素温度壳で冷却し ても亀裂を生じない材料は，液体へリウム温度まで 冷却される過程で亀裂を生じることはほとんどな $(27)$ 。
一般にエポキシ樹脂は，含浸材として次のような長 所在持っている。

（1）比較的低粘度（フェノール樹脂，不飽和ポリ エステルなどに比べて）であるため含浸し易い。

（2）硬化剂の選択によって，5 $150^{\circ} \mathrm{C} の$ 任意の 温度ですみやかに硬化する。

（3）硬化時の収縮が小さいので内部ひずみが少な く，機械的強度が大である。

（4）硬化時において，ガスや水などを発生しない ので, 含浸する際, 気泡やクラッグが入りにくい。

（5）金属などとの密着性がよく, 接着に圧力を必 要としない。

（6）低温物性が良好である。（特に機械的性質）

（7）硬化した樹脂は,すぐれた電気絶縁性を示す。

\section{3. 試験方法}

試料は液体窒素に浸漬したままと線を照射し，(そ れゆえ照射中の酸素の悪い影響はない) 圧縮試験を行 なった。压縮速度は $0.2 \mathrm{~mm} / \mathrm{min}$ (ひずみ速度 : 0.33 / min) に統一し, 応力ひずみ曲線から破断点応力, 破 断点ひずみを求めた。試験は各々 50 個の試験片につい て実施し, 度数折れ線を書き, $\gamma$ 線照射による度数折 れ線の変化によって，照射効果を評価した。

\section{4. 試験結果及び考察}

Fig. 2 に常温と液体窒素温度における，未照射試料 の代表的な応力一ひずみ線図を示す。常温で圧縮試験 を行なったものは〜100\%のひずみにおいても破断 には至らなかった。一方液体窒素温度で試験したもの は，降伏点を過ぎた箘所で破断に至る。また常温圧縮 に比心弾性係数も大きく, 降伏応力も高くなっている。 ただし, 圧縮試験機の硬さは有限かつ応力依存性があ り,また試料の粘性流動のため, 応力一ひずみ曲線は 弾性限度内でも直線とはならず, 緩やかなエス字を描 くので, 降伏点（または破断点）までの応力一ひずみ 


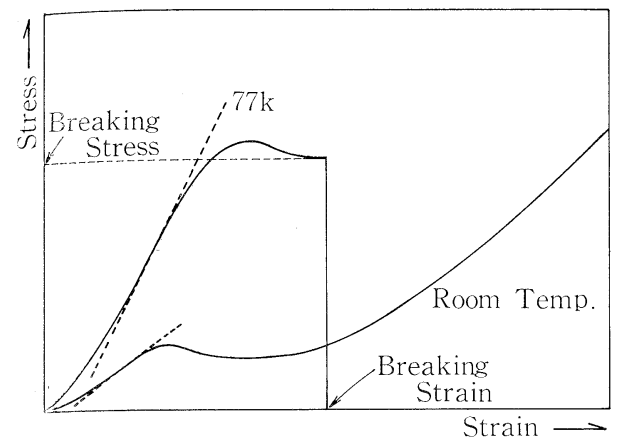

Fig. 2 Typical stress-strain curves obtained at LNT and RT. The maximum gradient of the solid lines is defined as the apparent elastic modulus (shown by the broken line) .

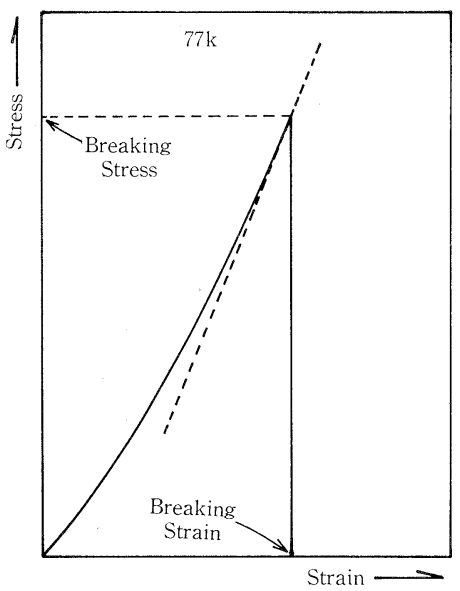

Fig. 3 Typical stress--strain curve of the samples showing extreme embrittling effect by irradiation.

曲線の一次微分が最大となる点の微分係数を, みかけ の弾性係数と定義した。(Fig. 2，Fig. 3 参照)

$\gamma$ 線照射を行ならと, Fig. 3 で示されるような, 降 伏点を示す以前に破断に至るものが若干現われ，線量 が増加すると，このよらな特性を示すものが増加し た。これらは破断点応力, 破断点ひずみとも未照射試 料と比較すると，極端に小さくなっている。Table 1 に線量とこの降伏点を示さないものの割合との関係を 示した。

Fig. 4 亿弾性係数の分布の， $\gamma$ 線照射による変化を 示してある。適合度検定（有意水準 0.05 )によると，

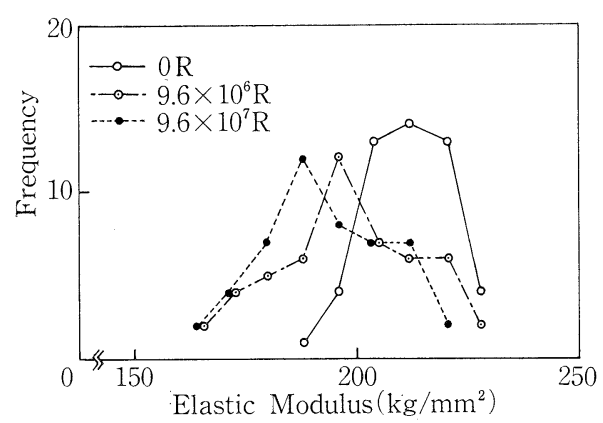

Fig. 4 Frequency polygon of measured values of elastic modulus.

どの分布もガウス分布とみなすことができる。そして 線量が増加するにつれて, 分布は弾性係数の小さい方 へ移動しているといえる。(Welch の検定)

この 2 つ照射挙動を考え合わせると，一次結合及 び主鎖の切断が起こっていると推定できる。

一般に高分子材料は，長鎖状分子より成り，それら が所々で一次結合の橋かけをしており,他の所では, フ アンデルワールス結合のごとき二次結合で結ばれた網 状構造をしている。高分子材料の粘弾性は, 主にこの 二次結合の応力緩和に負うところが多いが，弾性的挙 動は一次結合及び主鎖の弾性率に負うところが多い。 また限界応力も一次結合や主鎖の強度によって支配さ れる。こういら高分子に放射線が照射された場合，ま ず考えられるのは，架橋あるいは分子崩壊である。架

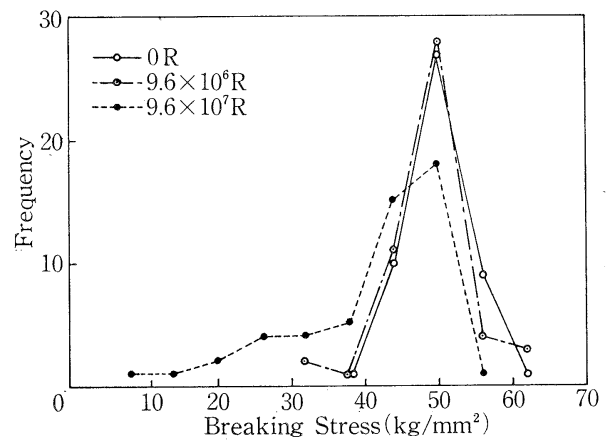

Fig. 5 Frequency polygon of measured values of breaking stress. The distribution of measured values of the irradiated samples up to $9.6 \times 10^{7} \mathrm{R}$ has a tail component which shows a deviation from the Gaussian curve. 


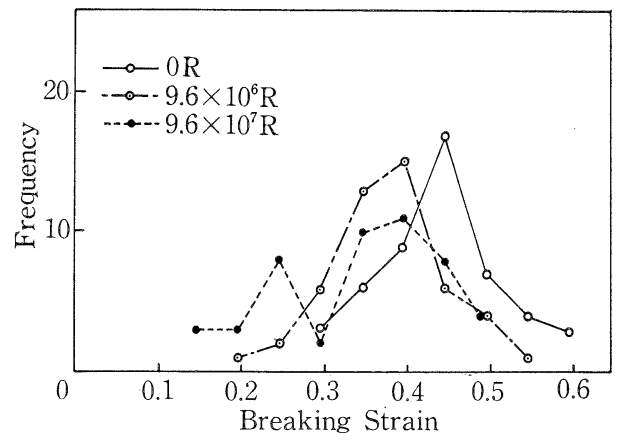

Fig. 6 Frequency polygon of measured values of breaking strain. The distribution of measured values of the irradiated samples up to $9.6 \times 10^{7} \mathrm{R}$ has a tail component which shows a deviation from the Gaussian curve.

橋型高分子の機械的強度は照射によって増加し，崩壊 型高分子のそれは減少するといわれている ${ }^{910)}$ 。

従って, 線量の増加に伴うみかけの弾性係数の低下 と, Fig. 3 のごとき限界応力の劣化を示すものの増加 を考え合わせると，主鎖切断が進行していると考える のが妥当であろう。

Fig. 5 に破断点応力の度数折れ線を, Fig. 6 に破断 点ひずみの度数折れ線を示す。適合度検定（有意水準 0.05) によると, 破断点応力, 破断点ひずみの分布と も照射線量 $0 \mathrm{R}, 9.6 \times 10^{6} \mathrm{R}$ の場合はガウス分布をし ているといえるが， $9.6 \times 10^{7} \mathrm{R}$ の場合はもは やガウス分布をしているとはいえない。ガウ ス分布で近似できる照射量 $0 \mathrm{R}$ と $9.6 \times 10^{6} \mathrm{R}$ の分布を比較する。破断点応力の 2 つ分布 には変化は認められない。一方, 破断点ひず みの分布では, $9.6 \times 10^{6} \mathrm{R}$ の照射を受けたも のの分布は未照射の分布より破断点ひずみの 小さい方へ移動している。(Welch の検定) さらに, $9.6 \times 10^{7} \mathrm{R}$ の分布をみると, 破断点 応力, 破断点ひずみとも Mode (最頻值) は $9.6 \times 10^{6} \mathrm{R}$ の分布と一致しているが，低い領 域に Fig. 3 で示されるような応力一ひずみ 曲線を持ち極端な脆化を示すもののため, 分 布に「裾の成分」が現われ，ガウス分布では 近似できない。それゆえ平均値が Mode（最 頻值) とかけ離れた值になっている。(Table
1 参照）以上のことから，この樹脂は照射脆化を起こ すと結論できる。

また, 各分布の Modeを比較してみると, その変化 は小さい。それゆえ, 少数の試験片による検査では, 結果が Mode 付近に偏り，「裾の成分」である極端な 脆化を示すものを見落し，変化を過少評価する恐れが ある。これは, ある物理量の測定值の分布は, 平均值 のまわりにガウス分布をするという統計的仮定が，破 綻をきたすためである。

弾性係数の小さい樹脂は, 低温でのじん性に富むと いうことが報告されている11)。しかし照射による弾性 係数の低下が, じん性の増加につながるわけでなく， 破断点ひずみの低下のため，逆にじん性は低下してい る。それゆえ，照射による弾性係数の変化はじん性に 対してあまり重要でなく, 破断点応力, 破断点ひずみ が大きく影響を与えているといえる。

実際のマグネットに使用された場合，低温であるの で，市箇所に異常部分が発生すると応力集中を起こ し，その結果局部的エネルギーの集中を起こし，これ が限界值に達した後は，自由エネルギーを減少しなが らどんどん成長し 全体へ至るという低温胣性を示す 11)。それゆえ， $10^{8} \mathrm{R}$ 程度以上の照射を受汀ると，極 端に脆化した箇所が応力集中の核となり, 電磁力と熱 応力のため局部的な含浸材の破断（または亀裂）が生 ずる。そこではもはやWire Movement を抑えるこ とができず, $(\sim 10 \mu$ 程度の,Wire Movement で電流劣 化が起こるといわれている。) その結果, Degradation や Training を再び起こすことになるであるう。

Table 1 Radiation induced change in various parameters concerning mechanical behaviors of Epoxy Resin.

\begin{tabular}{|c|c|c|c|}
\hline Gamma Dose & $0 \mathrm{R}$ & $9.6 \times 10^{6} \mathrm{R}$ & $9.6 \times 10^{7} \mathbb{R}$ \\
\hline $\begin{array}{c}\text { Fraction of Embrittled } \\
\text { Samples }\end{array}$ & $0 / 50$ & $6 / 50$ & $17 / 50$ \\
\hline $\begin{array}{l}\text { Average Value of Elastic } \\
\text { Moduli }\left(\mathrm{kg} / \mathrm{mm}^{2}\right)\end{array}$ & 211.5 & 197.4 & 184.9 \\
\hline $\begin{array}{l}\text { Mode of Elastic Moduli } \\
\left(\mathrm{kg} / \mathrm{mm}^{2}\right)\end{array}$ & 212.0 & 196.0 & 188.0 \\
\hline $\begin{array}{l}\text { Average Value of Breaking } \\
\text { Stress }\left(\mathrm{kg} / \mathrm{mm}^{2}\right)\end{array}$ & 49.9 & 49.8 & 43.5 \\
\hline Mode of Breaking Stress & 50.0 & 50.0 & 50.0 \\
\hline $\begin{array}{c}\text { Average Value of Breaking } \\
\text { Strain }\end{array}$ & 0.43 & 0.38 & 0.35 \\
\hline Mode of Breaking Strain & 0.44 & 0.39 & 0.39 \\
\hline
\end{tabular}

低温工学 
Wire Movement を支配すると考えられる含浸材の 性質, (i) 弾性係数, (ii) 破断点応力, 破断点ひずみ, に庼ぼす照射の影響について議論したが，(iii) 熱膨張 係数，(iv) 線材との接着性，については放射線の影響 は比較的少く, むしろ機械的欠陷（亀裂など）を通し て(iii) (iv) 八影響するものと考えられる。

実験は液体窒素温度で行なったが，実際は液体へリ ウム温度付近で使用されるため, いっそうの低温脆性 が予想される。それゆえ, 照射のための脆化が相乗す ると, 液体窒素温度の場合よりもクラックが導入され やすくなるものと思われる。

樹脂の機械特性, 熱特性, 電気特性を改良するのに 充てん剤を使用寸る場合が多い。しかし，含浸材とし て便用される場合, 熱膨張係数のちがいによる内部応 力が，(ii）破断点応力，破断点ひずみに影響を与える ことが考えられる。また, 熱伝導性を良くするものは, 電氞絶縁性を犠牲にするし, 電気絶縁性を向上させる ものは，熱伝導性を悪くするといら相反した問題を持 っている。さらに, それら複合材における照射効果も まだ明らかにされていない。実用材としては複合材の

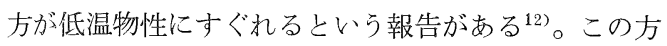
面の研究もさらに進められる心゙きであろう。

\section{5. 結言}

市販されているエポキシ系樹脂の大部分が主成分上 して含んでいるビスフェノールA系樹脂に, 液体空素 温度で $\gamma$ 線を照射して圧縮試験を行ない，検討したと ころ次のことがわかった。

（1）低温での $\gamma$ 線照射で，主鎖切断のためと思わ れる弾性係数の低下が見られた。

（2）一般に放射線に対して強いといわれるエポキ シ系樹脂でも， $10^{7}$ 8 $\mathrm{R}$ 程度の $\gamma$ 線照射で脆化を起こ す。特に, 少数ではあるが, 降伏点を示さず極端に脆 化するものがあらわれ, 線量が増加すると, この数も 増加する。そして含浸材として使用された場合, この 極端な脆化を示すものが問題になりそうである。

(3) 組織敏感量である破断点応力, 破断点ひずみ
の測定值の分布は，照射線量が増加寸るとガウス分布 で近似できなくなる。一方, 組織鈍感量である弾性係 数は, 線量が増加してもガウス分布はくずれない。そ れゆえ, 弾性係数などの組織鈍感量の測定については, 少数試験片による試験でもよいが，組織敏感量である 破断点応力，破断点ひずみなどの測定では，多くの試 験片による測定が必要である。

（4）樹脂の改良を目的とした充てん剂の使用は, 違った性質への寄与を充分考慮せ衩ばならない。また 複合材としての照射挙動を明らかにする必要がある。

含浸材の放射線照射効果を考える場合， $\gamma$ 線照射だ けでは不充分なので，現在低温中性子照射実験を計画 中である。

終りにあたり, 本研究の $\gamma$ 線照射のために協力して いただいた, 産業科学研究所の山本保氏に感謝いたし ます。

\section{参考 文献}

1) C. Laverick: Cryogenics 5 (1965) 152

2) H. Brechna: "Superconducting Magnet Systems" Springer-Berlin (1973)

3) G. M. McCracken, S. Blow : CLM-R 120 August (1975)

4) J. T.Kriese, D. Steiner : ORNL-TM-4256 (1972)

5) H. Ullmaier : Proc. Int. Conc. Radiation Effects and Tritium Technology for Fusion Reactors, Gatlinburg vol. II (1976) 403

6) J.F.Guess, et al : ORNL-TM-5187 (1975)

7) 垣内弘, 他：「エポキシ樹脂」昭晃堂 (1974)

8) 山村昌, 他：「超電導ハンドブック」電気学会 (1968)

9) O. Sysman, C. D. Bopp : ASTM-STP 208 (1956) 119

10) A. Charlesby: "Atomic Radiation and Polymers" Pergamon Press Ltd. England (1960)

11) B. Colyer, M. T. Ball, M. P. Campbell : Cryogenics 14 (1974) 281

12) G. Hartwing : IEEE Transaction on Magnetics Mag-11 (1975) 536 